\title{
The Correspondence of the Royal Institution for the Advancement of Learning in the McGill University Archives
}

by Réal G. Boulianne

The Royal Institution for the Advancement of Learning, which one associates generally with McGill University, was responsible also for the origin and development of the first system of public education in Lower Canada. Therefore, its correspondence, located in the McGill University Archives (MUA), is essential not only to the history of McGill, but also to the study of education in Quebec.

These documents were used extensively by Macmillan (1921) and Frost (1980 and 1984) in their bistories of McGill. This paper, bowever, will focus specifically on the contribution of these records to the bistoriographical controversy surrounding the initial development of public education in Quebec.

L'Institution royale pour l'avancement des sciences, que d'aucuns associent généralement à l'Université McGill, est également l'instigateur du premier système d'enseignement public du BasCanada. Par conséquent, sa correspondance, réunie dans les archives de l'Université McGill, est essentielle non seulement pour l'histoire de McGill mais pour l'étude de l'enseignement au Québec.

Ces documents ont été largement utilisés par Macmillan (1921) et Frost (1980 et 1984) dans leur bistoire de McGill. Néanmoins, cet article porte uniquement sur le rôle de ces documents dans la controverse historiographique qui entoure l'origine de l'enseignement public au Québec.

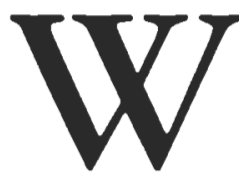

hen the Assembly of Lower Canada established the Royal Institution in $1801^{\mathrm{l}}$ it attempted to provide the colony with a much needed system of public education. Except for scattered local opposition, particularly in areas settled by recent immigrants from the U.S.A., the English-speaking population accepted these schools readily, and in most cases eagerly. However, since they came directly under the authority of the governor and were administered de facto by the Anglican Bishop of Quebec, the great majority of French Canadians refused to accept them, thus contributing to the failure of the Royal Institution to remain in the field of public education.

After the conquest, and more specifically after 1763 when Quebec became officially a British colony, the French Canadians feared, not without cause, ${ }^{2}$ that their new colonial masters would attempt to establish British institutions and to assimilate their new subjects into the English-speaking Protestant population of British North America. These fears were not alleviated when the English population of Quebec increased substantially with the coming of the Loyalists, leading to the passage of the Constitutional Act in 1791. This Act created a British system of representative government, and provided for land grants, the Clergy Reserves, for the support of a Protestant clergy. The structure to support a Protestant clergy was reinforced two years later when the Right Reverend Jacob Mountain was appointed Lord Bishop of the newly created See of Quebec. One of Mountain's first concerns was for the development of education.

Education, which had been neglected since the conquest, came eventually to the attention 
of the colonial authorities. The Governor, Lord Dorchester, formed a committee of the Legislative Council in 1787, under Chief Justice William Smith, to study the situation and to make recommendations for its improvement. At the same time he consulted Bishop Charles Inglis of Nova Scotia on the subject. Before the appointment of Jacob Mountain, Inglis included Quebec within his jurisdiction, and when he came on his visitation in 1789 , he proposed specific recommendations to improve education. A few months later, the Committee of the Legislative Council reported finally to the governor and proposed a state supported system of education to be crowned by a secular, non-sectarian college or university. However, in view of the opposition of $\mathrm{Mgr}$. Hubert, the Roman Catholic Bishop of Quebec, nothing was done to implement this.

The Smith proposal may not have been implemented, but a similar plan was formulated a few years later by Bishop Mountain who was interested not only in improving education for the English of Lower Canada, but also in using it to help integrate the French and English-speaking subjects of the Crown into a united Anglo-Protestant population. He wrote about this to Dorchester in 1795.

I would also beg leave to introduce here a subject by no means remotely connected with that which I have thus far had the honor of submitting. I mean the general state of Education in this Province. Had the appointment of $S$. Masters taken place under your L's Administration, I have no doubt that we should have found the bounty of Gov't accurately applied to the purposes for which it was originally designed - the liberal instruction of youth; the inducing the Inhabitants to embrace by degrees the Protestant Religion - etc. - At present, it is a matter of sufficient notoriety that either from incapacity or inattention in the Parties employed there is not a Grammar School in the Province that is worthy of the name, - that of inferior Schools there are none which proceed upon the prin- ciples stated above. This abuse is of great public moment. The almost inevitable necessity which will thus be imposed upon the higher orders of Society to send their Children to the United States for the completion of their Education is pregnant with alarming mischiefs. ${ }^{3}$

Mountain's proposal was supported by the colonial administration. Through the efforts of the Lieutenant-Governor, Sir Robert Shore Milnes, his Civil Secretary, Herman Witsius Ryland, and the Attorney General, Jonathan Sewell, none of whom was particularly sympathetic to the aspirations of the French Canadians, legislation was enacted in 1801 establishing the Royal Institution for the Advancement of Learning.

\section{THE EDUCATION ACT OF 1801}

The Act of 1801 created the structure for a centralized, state supported system of education in Lower Canada. The governor was authorized to appoint a board of trustees to administer the system and to make rules and regulations for the schools under its control. In addition, he was to name commissioners and visitors, local residents responsible for the construction and supervision of schools. Furthermore, he was to license all teachers and issue government warrants for their salaries. The law placed a great deal of authority in the hands of the governor and, effectively, in those of the proposed board of trustees. Like the Smith proposal of 1789 , it provided for elementary schools in villages and parishes, intermediate schools at the county level, as well as a college or university.

The Roman Catholic Church, which had opposed the 1789 project, now, under the leadership of Mgr. Plessis, similarly opposed the Royal Institution. It feared the interference of the state in a jurisdiction it claimed as its own. As well, it was afraid that the schools would be used to anglicize and protestantize the French Canadians, certainly a stated aim of Mountain and the colonial authorities.

This opposition was one of the reasons for the eventual failure of the Royal Institution to create a school system in fact as well as in law. 
contrinedo thall extend to alter or prejudice the Right of His Majefty, His Heirs or Succeffor a, or thole of any Perion or Perfons, or Body Politic or Corporace whatfoever, zot particularly mentioned in this $\mathrm{AA}$.

nulie Aa.

XVI. And be it further enaled by the Authority aforefrid, that this $A Q$ fhall bo deemed and saken to be a Public AQt, and sll Judgen, Juftices and other Perfons are hereb.

$$
\text { C A P, XVII. }
$$

2.alds - An Acr for the Eftablithment of Free Schools and the Advancement of 12ald $2 x-7 x$. Learning in this Province.

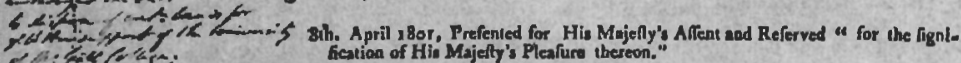

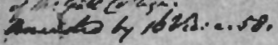

7the April 1802, Altented to by His Majally in Hits Pring Couneil.

122h Augun isoz, The Rayal Alfent fignifiad by Proctamation of Hit Exestlency

MOST GRACIOUS SOVEREIGN.

W WHEREAS Your Majefy from yoor Patemal Regard, for the wellare and prot perity of your Subjeets of this Province, hath been mof graciount plealed to give direlions, for eflablifiniog of a competent namber of Free Schiools for the inflruce. tion of their Children, in the Gir R Rudiments of ufesal Lamings and alfor octer fion may require, for Foundatioas of a more enlarged and comprebenfive nature í And wheres Your Mnjefly bach been further moll graciou fly pleafed to fignify your Roy al Intea. tione, chat a fritable proportion of the Lands of the Crown, be fet a part, and the revonue thereof appropriated to fuch purpofes, Therefore We, Your Majefty'o Faithful

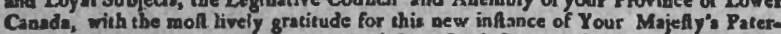
nal Atteotion, to the wasts of Your Majefly's Subjeds, and defirone to contribute every thing in our power, for the execueion of a plan to peculiarly benchicial to the

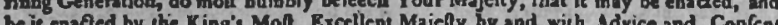
be it Gnaled by hie King Mol

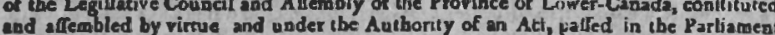
of Great Britain, intitnled, "An $A Q$ to zepeal certain paris of an $A Q$ palfed in "the fouzceenth Year of His Majehy's Reign, intituled, "An Ad for malung more

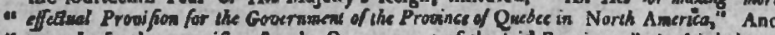
- Lo matro further provifion for the Governmeat of the laid Province :" And it is here-
A. D. 1801. Anno Quadragefimo Primo Georgii III. C. 16-17:

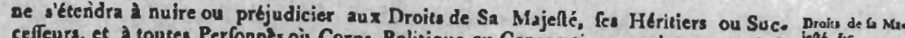
ceffeurs, et a toutes Perfonnts oì Corps Politique ou Corporations quetcongues, lef-

XVI. Et qu'il foit de plus ftatue par l'Autorite fufdite, que cet Aate ferz cenff

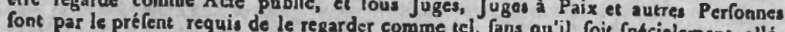
gut.

$$
\text { C A. P. XVII. }
$$
Act s pour l'Etabliffement d'Ecoles Gratuites, et l'Avancement des Science

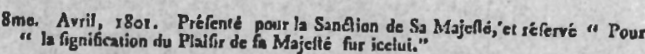
7mes Avril, 1802. Sandionne par fá Majenté danu fon Confeil Prive

rame. Aoút, 1802. La Sundion Royale detasce par Proclatiation de fon Ex-

TRES GRACEUX SOUVERAIN,

VU que Votre Majent, par fes Egards, Paternels pour le bien-etre et la profpedirections pour l' fruation de leurs Enfans dana les premiers Elements des Sciescestuites pour lin-

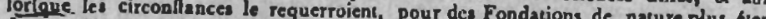
due; et Vu que Votre Majele a encore bien voulu Gyoifer Très Grace plus tienIntentions Royales pour qu'une proportion convenable des terres de la Conronn

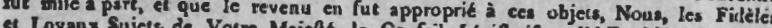

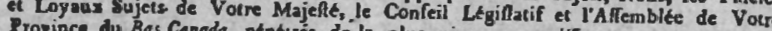
velle marque de l'altention Paternelle de Voure Majellt Votre Majefte, et délirant contribuer, en tout ce gui eft en notre pouvoin syjels, do on aun plad if puriculieremont avantageux à la Gentration paillante, Supplione ca confequence tres humbiement Vore Majene quili. puiffe tere fatue, et quitl foic fa tuk par a Tres Excellente Majefte du Roi, par et de l'Avis et Confentement du fembles en Vertu et fous rAube de la Province du Bas. Canada, confliuts et af

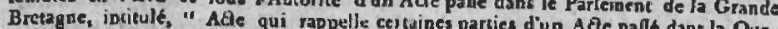

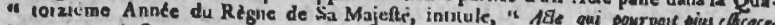

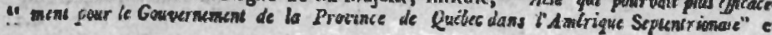

Figure 1. The act establishing the Royal Institution, from Provincial Statutes of Lower Canada, volume III, 1801. (Government Documents Department, McGill University Libraries). 


\section{The Correspondence of the Royal Institution}

Another was the lack of support from the Crown which never fulfilled its promises to provide land grants to help finance the schools. ${ }^{4}$ Also, after 1814, the Assembly, year after year, fought to pass legislation more suitable for population in the great majority French and Roman Catholic.'

From 1801 to 1818 the Royal Institution was essentially a dead letter. The governor never appointed a board of trustees, and those schools for which the government paid a teacher's salary had neither direction nor adequate supervision. In 1801 there were four of these, and by 1818 their number had risen to thirty-five. However, under these conditions, many had become mere sinecures, often seen as rewards for good and faithful servants of the government. ${ }^{6}$ The Royal Institution, as a system of education, was virtually non-existent.

The death of James McGill in 1813 helped change the situation. His will provided $£ 10,000$ and his Burnside Estate for the creation, within ten years of his death, of a college or university bearing his name. His executors, one of whom was the Rev. John Strachan of Upper Canada, finding it difficult to realize the bequest, linked their fortunes to that of the Royal Institution. ${ }^{7}$ In 1816, Strachan wrote to Mountain to this effect and suggested that the government might move on the Royal Institution. ${ }^{8}$ It did. On October 8,1818 , the Governor-General, the Duke of Richmond, issued Letters-Patent establishing the Royal Institution, and all those schools receiving government salaries were placed under its jurisdiction. The Board of Trustees was appointed and, on December 4, 1819, Bishop Mountain was named Principal. ${ }^{9}$ Mountain named the Rev. Joseph Langley Mills, Chaplain to the Forces, as its Secretary ${ }^{10}$ and the Board of 'Trustees held its first meeting in January, $1820 .^{11}$

\section{The first Board, headed by Bishop} Mountain, was made up principally of members of the colonial administration, representatives from the Executive and Legislative Councils as well as from the judiciary of both Lower and Upper Canada. ${ }^{12} \mathrm{Mgr}$. Plessis was nominated to the Board but, as could be expected, refused to serve on a body so predominantly English and Protestant in which he would have been subservient to the Anglican Bishop. His refusal meant the continued opposition of the Roman Catholic clergy, the same situation that had hindered the Royal Institution since 1801.

Nevertheless, the Board carried on with its task of trying to make the Royal Institution not only the official system of education in Lower Canada, but also an effective one. It promulgated a set of regulations which, for the time, appeared fair and liberal. Uniformity of textbooks was prescribed, and their selection was left to the clergy of both denominations for the schools in their respective parishes. Priests and ministers were invited and authorized to inspect the schools and to visit the pupils of their denomination. Furthermore, provisions were made for separate religious worship. In addition, in French-speaking areas, the teachers appointed were to be French and Roman Catholic. The visitors, local residents, were to report to the Royal Institution through its Secretary ${ }^{13}$

From 1820 onward, with a central administration in place, the Royal Institution began to expand, albeit mostly in English-speaking areas. This expansion, especially in the Eastern Townships and in western Lower Canada, was due in good part to the efforts of the Society for the Propagation of the Gospel in Foreign Parts (SPG) missionaries who saw the development of education an integral part of their mission. There had been thirty-five government supported schools, although unorganized as a system, in 1818. By 1824, there were fortyone, and by 1829 , eighty-four. ${ }^{14}$ These schools now came under the direct supervision of the Royal Institution, the SPG missionaries and the visitors reporting regularly on their progress to the Secretary.

Since the great majority of the French Canadians did not participate in the state school system, the colonial authorities took steps to alter it to make it more acceptable to them and to the Roman Catholic Church. As early as 1821, shortly after the Royal Institution started its operation, the GovernorGeneral, Lord Dalhousie, initiated negotiations with the Roman Catholic hierarchy to find an acceptable solution to this situation. These negotiations between the governor(s) 
and Mgr. Plessis, and after his death with his successor, Mgr. Panet, went on very slowly from 1821 to 1829 . An agreement was reached finally that year to form two virtually independent committees of the Royal Institution, one for the Roman Catholics under the authority of their bishop, and the other for the Protestants, under the Anglican bishop - a system not unlike the one which governed Quebec education from the middle of the 19th century until 1964! On March 2, 1829, the Legislative Council presented the text of the bill to the Assembly. Although the bill received first reading, it was not passed but was referred to the next session. ${ }^{15}$

The Assembly then passed its own education legislation for Lower Canada, the Syndics' Act, which was sanctioned by the Administrator of the Province on March 14, 1829. ${ }^{16}$ Although the Act did not suppress the Royal Institution nor its financial support, it offered the residents of Lower Canada an alternate system, one supported more generously by state funds. After much activity since 1814 , the Assembly, rather than the colonial authorities and the churches, had managed finally to place itself in control of public education.

The effect of the Syndics' Act was to eliminate the need for the Royal Institution to continue its activities in the field of public education. From 1829 on ward, the number of Royal Institution schools declined. From a peak of eighty-four schools in 1829, there were only sixty-two left in 1831, and three in 1844. By 1846 it had no elementary schools left under its jurisdiction. ${ }^{17}$ In fact, after 1837 , the Royal Institution had narrowed its interest primarily to its grammar schools in Montreal and Quebec City and to McGill College.

\section{THE ACT OF 1801 AND CANADIAN HISTORIOGRAPHY}

Until the publication of volumes III and IV of Louis-Philippe Audet's Le Système scolaire de la Province de Québec in $1952{ }^{18}$ there had been no really comprehensive and well documented study of the Royal Institution. Most historians, particularly French-language historians, had seen in this school system an attempt, if not a plot, by the colonial author- ities to assimilate the French Canadians. François-Xavier Garneau, whose influence on French-Canadian historiography is well known, took this stand firmly.

On autorisa également l'établissement de l'Institution Royale, crée en apparence pour "l'encouragement de l'instruction publique", mais destinée, dans la pensée de ses promoteurs à faciliter l'anglicisation du pays. La direction de l'enseignement, par cette dernière mesure, se trouva entre les mains du pouvoir exécutif. Le gouverneur nomma les administrateurs, désigna les paroisses où l'on ouvrirait des écoles, choisit des instituteurs; et à sa demande le roi dota en terres deux collèges qu'on se proposait de fonder, l'un à Québec, l'autre à Montréal. L'évêque protestant fut appelé à la présidence de l'Institu. tion: cela la rendit impopulaire dès le principe. [Au surplus, elle n'exista jamais que de nom.] Les Canadiens, qui ne voulaient abjurer ni leur langue, ni leurs autels, la repoussèrent; et elle ne servit, pendant plus d'un quart de siècle, qu'à mettre obstacle à un système d'éducation plus conforme à leurs
voeux.

This evaluation became essentially, with very few exceptions, the standard interpretation of the work of the Royal Institution for approximately one hundred years. These conclusions were based solely on the correspondence of the colonial officials and of the Roman Catholic clergy in the early 19 th century. The records of the Royal Institution were neither cited nor used.

Dr. J.-B. Meilleur, Superintendent of Education for Lower Canada from 1842 to 1855 , published a history of education in the Province. ${ }^{20}$ Meilleur had been also, as a member of the Assembly, an active participant on its education committee while the Royal Institution had still been in operation, and as such, knew of its activities and of its records. This put him in a good position to evaluate its contribution to the development of public 
The Correspondence of the Royal Institution

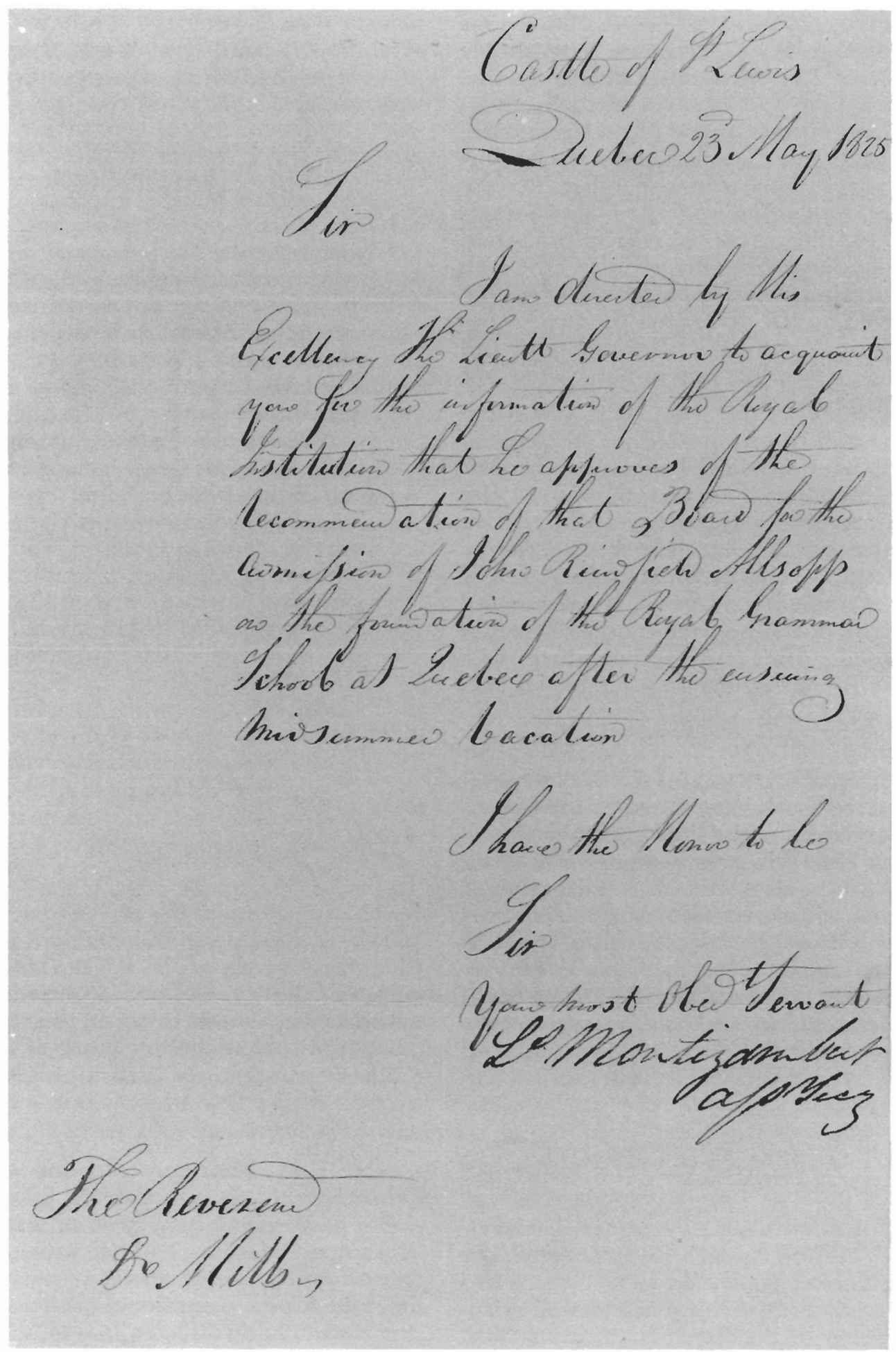

Figure 2. Appointment of John Allsopp to the Royal Grammer School, Quebec, 23 May, 1825. (Royal Institution Papers, McGill University Archives.) 


\section{The Correspondence of the Royal Institution}

education in Lower Canada. Yet, his conclusions were virtually the same as Garneau's.

Cette loi, destinée à servir de base, dans l'esprit des auteurs, à l'anglification de l'origine française en Canada, par un système d'instruction publique sécularisé, et fonctionnant en anglais... ${ }^{21}$

Le gouvernement et l'Institution royale avaient, en vertu de cette loi, la liberté de monopoliser le pouvoir en faveur de l'Eglise anglicane... ${ }^{22}$

A more complete study of the Royal Institution might have been expected from someone in Meilleur's position. However, like Garneau, he went no further than to examine the intentions of the founders in 1801 .

A more valid evaluation of the work of the Royal Institution was written in 1914 by George W. Parmelee, Director of Protestant Education from 1924 to 1930 . In his article, "English Education," in Canada and Its Provinces, ${ }^{23}$ he engaged the issue of the Royal Institution more fully than previous historians. Making use of the correspondence of the Royal Institution, he was able to examine in some detail the actual operation of the school system and to refute, with compelling historical evidence, some of the more inflamatory charges against it. In using the Royal Institution records to correct some of these earlier inaccuracies and accusations, Parmelee made a substanital, if generally unnoticed, contribution to the history of that institution.

Like Parmelee, Cyrus Macmillan in McGill and Its Story, 1821-1921, ${ }^{24}$ used the Royal Institution correspondence and described, to some extent, the actual operation of the school system after 1820 . Likewise, he looked beyond the intentions of the founders in 1801 .

Unfortunately, neither Parmelee's nor Macmillan's evaluation of the Royal Institution made an impact on Canadian historiography. Yet, it is difficult to understand how serious scholars, writing on the subject after 1921, could have ignored their contribution.

It is quite evident that Lionel Groulx in L'Enseignement français au Canada, published in 1931, had consulted both Parmelee and
Macmillan. Despite this, in his twenty page treatment of the Royal Institution, the most detailed study of the subject yet, he neglected to take their contribution into account. He still saw only the plot of the colonial authorities to assimilate the French Canadians and made no reference to the Royal Institution in its operational phase after 1820 , its most productive years as a school system.

...enfin, fondation d'un système d'écoles anglaises avec maîtres dirigés et payés par le gouvernement pour enseigner l'anglais gratuitement au Canadiens. ${ }^{25}$

Il y a lieu de se demander si monopole d'état plus vigoureusement organisé, mainmise plus absolue des autorités coloniales sur l'esprit des prochaines générations, pouvaient être imaginées. ${ }^{26}$

Groulx continued to perpetuate the Garneau position even though he had to be aware, through his knowledge of Parmelee and Macmillan, that there had been more to the Royal Institution than the initial intentions of the colonial authorities, and that there were documents available to pursue this line of inquiry further. This was a serious omission for a historian of Groulx's stature and influence. Unfortunately, the Garneau-Groulx interpretation continued to prevail in subsequent histories. Authors like Bruchesi (1951), Rumilly (1951), and even Mason Wade (1955) and others, accepted the same interpretation. ${ }^{27}$

It took a general history of Canada, Arthur Lower's Colony to Nation, published in 1946, to introduce some new and interesting insights on the subject. Lower's hypothesis challenged seriously the traditional interpretation that the Royal Institution had been designed specifically to assimilate the French Canadians.

The Royal Institution is held up by many French Canadians today as an example of the 'tyranny' to which their ancestors were subject, another English attempt to anglicize and proselytize them. Complete purity of motive need not be attributed to the authors of the project 
but a reading of the Act in the spirit of English parliamentary institutions suggests that it contained little that could not have been used by French and Catholic people to their own advantage. Too much power was given to The Governor, yet as early as 1802 those words had some similarity to The Crown. The first membership of the Institution was far too heavily weighted with English and for that (a condition common to every phase of government in the province at that time) there is no defense. Yet if the French people had taken the Act and worked it, as they afterwards worked Responsible Government, they would sooner or later have brought matters to the same point of democratic control and would have had a system of free elementary education long before they actually obtained it. The difficulty lay not so much in the Act as in French misunderstanding of the genius of English institutions, especially of the great part of government that resides in convention rather than in law; and it lay still more in the opposition of bishop and clergy, who, not finding themselves given specific mention and place under the terms of the Act, believed they were shouldered out of the all-important field of education. But they too, a reading of the Act would suggest, could have found their place in the scheme, if they had desired it. They did not desire it: they thought in terms of a church which should have a position in society independent of, if not superior to, the state, not of a church subject to the general law of the land. The charge of tyranny would seem to have little foundation when levelled against an act carried in an assembly of which the great majority were French and Catholic. ${ }^{28}$

It is worth noting that Lower, in a general history of Canada, could present such a fresh, interesting, if largely unsubstantiated hypothesis. However, it was a hypothesis worth exploring.

Two years later, in 1948 Louis-Philippe Audet presented a brief paper on the Royal Institution to the Royal Society of Canada. Although he did not make reference to Lower, (there is no way of knowing whether or not he had read Lower) he presented essentially the Lower hypothesis.

Ce rapport est significatif. Ces paroisses qui ont accepté et utilisé, pour l'éducation de la jeunesse, la loi de 1801, ont-elles pris une attitude si anti-nationale et compromis les principes religieux et patriotiques de leurs ressortissants? $\mathrm{Si}$, au lieu de onze paroisses, la plupart avaient sollicité l'appui du pouvoir public, et si l'autorité religieuse avait pris les précautions nécessaires pour sauvegarder la foi de ses ouailles, les résultats n'auraient-ils pas été totalement differents? La politique d'abstention nous a joué dans le passé de fort mauvais tours. La collaboration franche et loyale sur une base équitable qui sauvegarde les droits de chacun est autrement féconde. Cette dernière attitude est même la seul qui nous permette de revendiquer nos droits avec quelque chance d'être entendus. Notre histoire eût été tout autre si nous l'avions compris plus tôt. ${ }^{29}$

The major significance of this article is not that it brought much new information to light. It did not. There was not even a reference to the now virtually forgotten Royal Institution documents used by Parmelee and Macmillan some thirty years previously. However, the hypothesis presented and the questions raised pointed directly to the need for a detailed study of the Royal Institution, one based not solely on the writings of colonial authorities, but one which examined thoroughly the actual operation of the Royal Institution as a school system and the fate of those French Canadians who had accepted its authority. Audet's hypothesis would lead him to re-discover the records of the Royal Institution. 


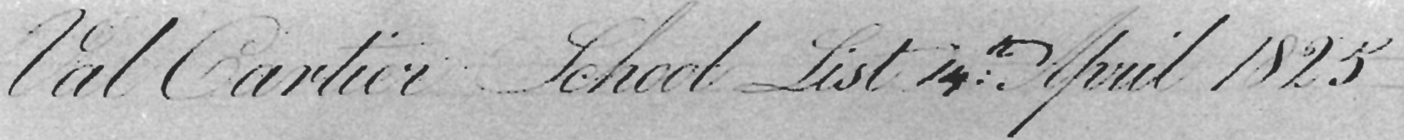

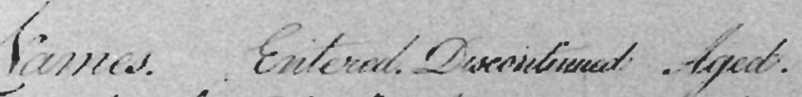

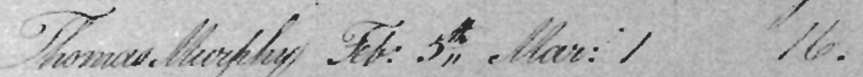

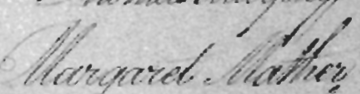

fond Hather:

yivarne Gerente

Cteques Govinis.

Qunterisid perer

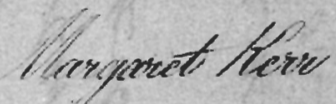

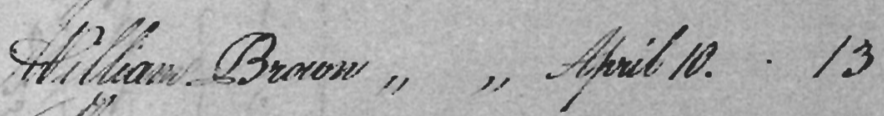

Parume Prowory

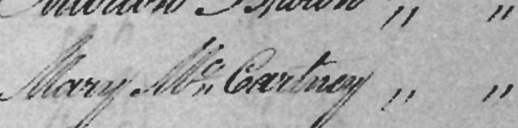

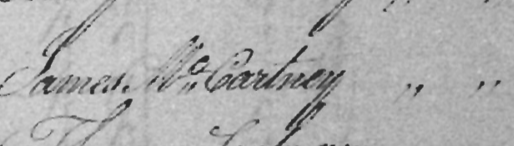

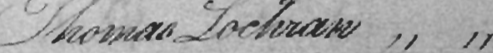

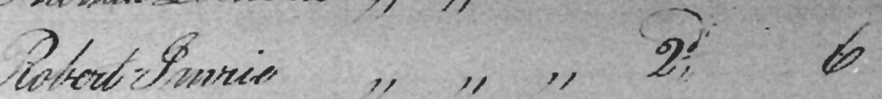

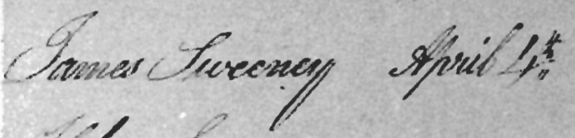

teclen checenuest

pereque therey

covisa hasuery

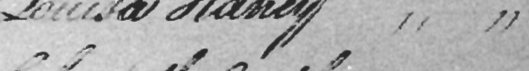

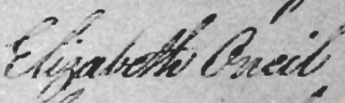

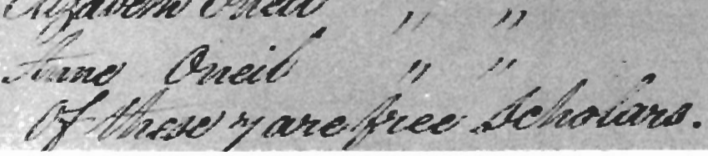

colcessis.

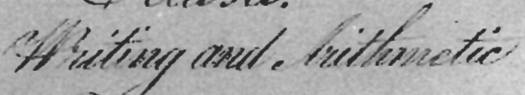

f

6

9

$y$

if

- 2) Penctering.

yip.

$13 \frac{8}{3}$

$\frac{60}{20}$

(2):

Figure 3. Report from the school at Val Cartier, 14 April 1825. (Royal Institution Papers, McGill University Archives.) 


\section{THE ROYAL INSTITUTION CORRESPONDENCE AND THE MCGILL UNIVERSITY ARCHIVES}

The search for the Royal Institution documents took Audet, quite logically, to McGill Univeristy. Although McGill had no archives as yet, with the help of the Principal, F. Cyril James, the correspondence of the Royal Institution was located among the stored papers of the Board of Governors of the university. There were three different kinds of documents:

1. Letter-Books, 1820-1858;

2. Incoming Correspondence, 1820-1853;

3. Minute-Books, 1837-1856.

With these documents at his disposal, Audet began his task of writing the history of the Royal Institution.

It was fourteen years later, in August 1962, that McGill established the MUA. To the first archivist, A. D. Ridge, fell the task of putting order in the McGill University papers, including those of the Royal Institution. The first of these documents to be entered into the archives were the Letter-Books, as Accession 100, on December 18, 1963. The second was the Incoming Correspondence, on December 16, 1965, as Accession 447, and the last the Minute-Books, on April 3, 1967, as Accession 681. These four accessions are now part of Record Group 4: Secretariat of the Royal Institution for the Advancement of Learning and the Board of Governors.

These six Letter-Books, beginning 22 April 1820 and ending 29 September 1858, are hand written copies of outgoing correspondence (the practice before carbon paper and other duplicating methods) written by the Secretary of the Royal Institution. They are in chronological order and they contain the directives and inquiries of the Board of Trustees, through the hands of the Secretary, to commissioners, visitors, teachers, Anglican and other clergymen, as well as to the governor and other colonial officials. This today would represent, more or less, the correspondence and directives coming from a provincial department of education.
The Incoming Correspondence, 1820-1853, was organized into 113 packets of letters, bundled more or less chronologically, each bundle containing generally the correspondence for a quarter of a year.

These are packets of original lettters received by the Royal Institution, written generally to the Secretary. Since the letters are bundled only chronologically, letters in any packet might come from hundreds of people from a variety of regions in the province. ${ }^{30} \mathrm{~A}$ considerable part of this correspondence is made up of school reports from the visitors as well as letters to the Secretary from the SPG missionaries regarding the schools in their missions. There are letters also from commissioners, visitors, teachers, parents, and other local officials. This correspondence describes essentially the local operation of the various schools with their issues, problems, and controversies. Today, it would represent the activities of education at the school board level.

The two volumes of Minute-Books, begin on 3 February 1837 and conclude on 13 June 1856. These contain the deliberations of the Board of Trustees. Its policies were implemented by the Secretary, and were reflected in his correspondence.

Unfortunately, the Minute-Book(s) from 1820 to 1837 are missing. This represents a serious gap in the Royal Institution documentation, particularly for the period when that body's primary focus was public education. However, the gap is not as critical as it might appear. The major decisions and directives of the Board can be reconstructed quite readily from the Secretary's correspondence in which he often refers to Board decisions and Board policies. In addition, he wrote comments on the covers of the incoming letters making further reference to the Board of Trustees. Nevertheless, the availability of these MinuteBooks would simplify the researcher's task and would give an imprimatur to what are now deductions, sound though they might be. Moreover, these books might well have contained other information which the Secretary had no need, nor wish, to communicate to others. Finding these Minute-Books would certainly contribute to a further understanding of the Royal Institution. 


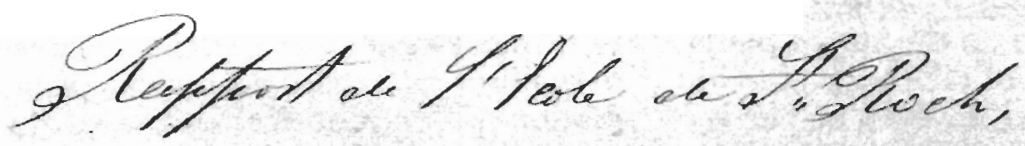

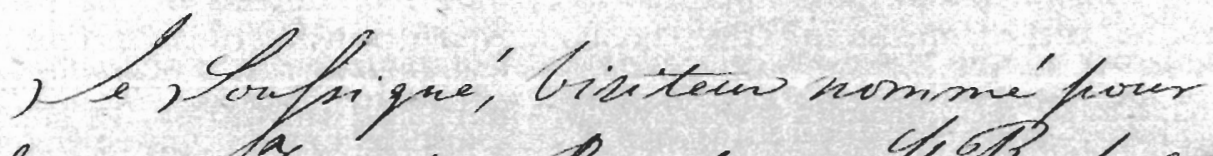

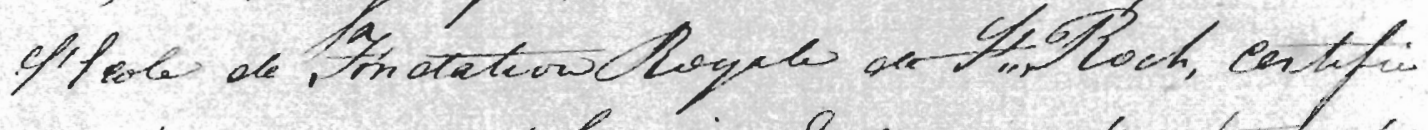
avois excamine 'fe dicle feras que f'on trowné dems un eílt al propioutié?

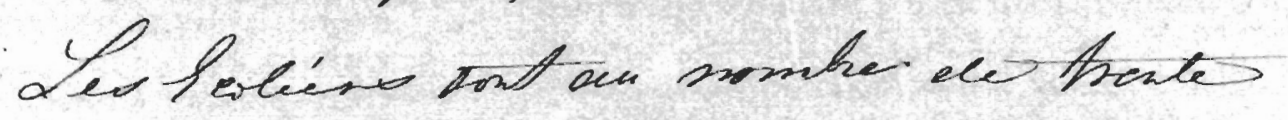

deuw, dont quationg trit adnue goder.

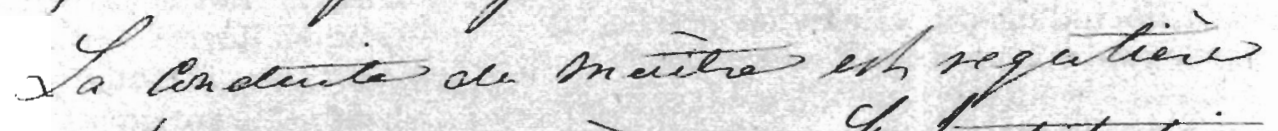

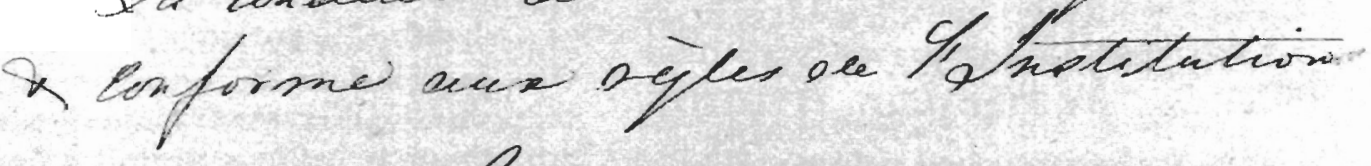

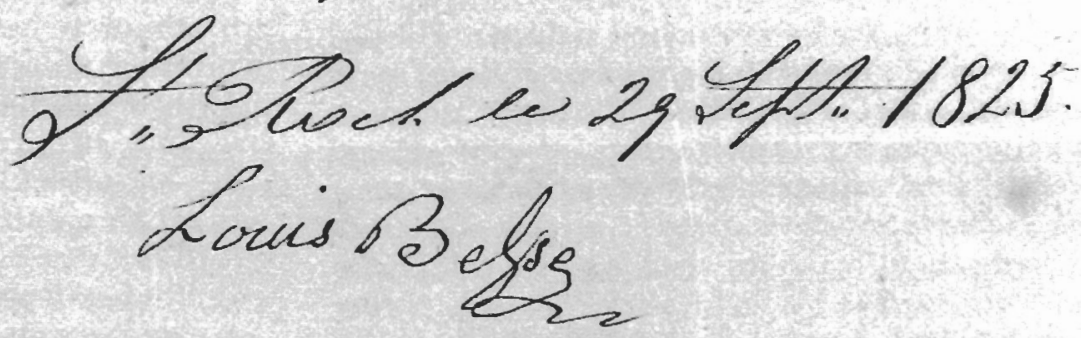

Figure 4 .Report from the school at St. Roch, 29 September 1825. (Royal Institution Papers, McGill University Archives.) 


\section{The Correspondence of the Royal Institution}

Audet's re-discovery of the Royal Institution documents was going to make an impact on Canadian historiography. No longer could historians focus solely on the founding of the school system in 1801 and on the stated plans of its originators. The gap of relative inactivity from 1801 to 1818 would have to be recognized and explained, and more importantly, the actual, not alleged, operation of the schools would have to be considered. Moreover, it would have to be recognized also that, with the possible exception of Bishop Mountain, the people who administered the school system after 1820 were different from those who had initiated the law in 1801. Even Bishop Mountain, in his latter years (he died in 1825) was a far different person from the energetic and somewhat autocratic prelate who arrived in 1793 determined to establish the Church of England in the Canadas. $\mathrm{He}$ was an older, wiser, and to a great extent disillusioned man who had made his peace reluctantly with the conditions of the colonial church in Lower Canada, including the somewhat privileged position of the Church of Rome.

\section{LOUIS-PHILIPPE AUDET AND THE HISTORY OF THE ROYAL INSTITUTION}

In 1952, Audet published volumes III and IV of his six volume Le Système scolaire de la Province de Québec. These 739 pages, devoted exclusively to the history of the Royal Institution, represented by far the most comprehensive study yet. Prior to this, Groulx's twenty pages had been the longest work on the subject, and as has been stated already, a very imcomplete, some might say biased, treatment indeed.

Audet re-examined, as others had done, the conditions under which the Act was passed in 1801 as well as the controversy that had followed. More importantly, however, he concentrated on the Royal Institution as an operational system of education. He identified the schools and examined their textbooks, programs of study, and pedagogical problems. He studied the teachers, their methods, competence, salaries, pensions, etc.., as well as the work of the local of ficials, the commissioners and visitors. He examined the activities of the central authorities, the principal, the Board of
Trustees, and the Secretary. He looked at the regulations of the Board and at its administrative and financial problems. In addition, he outlined the attempts of the governor to reform the system to make it more acceptable to the French Canadians by proposing the formation of two identical and virtually autonomous committees of the Royal Institution. Audet even described the foundation and early history of McGill in the context of the work of the Royal Institution. In all, he produced a most thorough and scholarly history of Quebec's first education act. His conclusions were similar to those of his 1948 article which had served as his hypothesis.

Concluons. À la lumière des innombrables pièces d'archives que nous avons consultées, des procèsverbaux du Bureau et surtout de la correspondance officielle de l'Institution Royale, nous estimons que le jugement de l'histoire sur la loi scolaire de 1801 et sur le rôle de l'Institution Royale devrait être le suivant: sans minimiser l'influence de Jacob Mountain et de Jonathan Sewell dans l'élaboration du projet de 1801 , il reste évident que le texte de cette loi ne contient à peu près rien qui n'aurait pu être utilisé par les Canadiens français catholiques à leur propre avantage. Les provisos des articles 4 et 8 , soustrayant les écoles catholique à l'autorité de l'Institution Royale, constituent, à toutes fins pratiques, un système scolaire pour les Canadiens de langue anglaise, mais avec l'espérance que les Canadiens français voudront, eux aussi, en profiter. Il est faux de dire que l'Institution Royale fut un organisme tyrannique qui s'appliqua à défranciser et à décatholiciser les Canadiens: les documents historiques prouvent le contraire. Enfin, même si elle a rendu assez peu de services à la population canadienne-française, l'Institution Royale ne fut pas une faillite, car elle contribua à l'éducation de la jeunesse de langue anglaise dans les trois domaines de 


\section{The Correspondence of the Royal Institution}

l'enseignement élémentaire, secondaire et supérieur. Tout compte fait, elle fut une pierre d'attente, ou mieux encore, une étape décisive dans la conquête de nos libertés scolaires, préparant ainsi une ère de justice pour tous. ${ }^{31}$

Audet's study was long overdue. It not only refuted quite conclusively the charges of a nefarious plot to use education to assimilate the French Canadians but it established also the relative importance of the Royal Institution in the history of Lower Canada. The records of the Royal Institution made this major contribution to Canadian historiography possible.

\section{THE ROYAL INSTITUTION DOCUMENTS AND FURTHER STUDIES}

Although Audet had gone through the complete records of the Royal Institution, he had not come near exhausting their data. A wealth of information remained, and still remains, to be used by researchers.

A topic which Audet had explored only sufficiently to support his hypothesis remained to be explored further - a study focusing specifically on those French-Canadian parishes that had accepted to operate schools under the Royal Institution, as well as the fate of those French-Canadian pupils who had attended Royal Institution schools under English adminstration. Audet had made a start in this direction when, in 1956, he wrote a paper, once more for the Royal Society of Canada: "Deux Écoles royales, 1814-1836: Sainte-Marie de la Nouvelle Beauce et Cap Santé," in which he presented a complete history of the Royal Institution schools in these two FrenchCanadian parishes. The result of these studies reinforced his previous conclusions.

Rien encore dans tout cela d'une offensive concertée pour angliciser et protestantiser les Canadiens!

Il me semble, pour ma part, que si les chefs religieux et civils du BasCanada avaient accepté cette loi de 1801 et décidé de l'utiliser, comme nos parlementaires le firent pour le gouvernement responsable, ils auraient tôt ou tard amené les chose au même point de contrôle démocratique et auraient réussi à obtenir un système d'écoles gratuites, bien avant l'époque où ils les obtinrent en réalité. ${ }^{32}$

Audet had studied only two FrenchCanadian schools in detail. There were more. In 1818 there had been eleven French-Candian schools in Roman Catholic parishes, ${ }^{33}$ and over the years there were some twenty schools where the French Canadians had been in the great majority, or had formed a substantial proportion of the student body of large English administered schools. ${ }^{34}$ The fate of virtually all the French-Canadian pupils in Royal Institution schools remained to be studied. This is what this writer did in 1964 in a M.A. thesis presented to the Department of History of the University of Ottawa: "The French Canadians under the Royal Institution for the Advancement of Learning, 1818-1829," and in a subsequent article in Histoire Sociale/Social History in $1972 .{ }^{35}$

These studies, based almost exclusively on the Royal Institution documents, focused on virtually all those French Canadians who had come under its administration. The following topics were examined: the origin and development of the schools; the identification of the pupils, teachers, commissioners, visitors; the curriculum and textbooks; the local administration of the schools and relations with the central authorities; the role of clergymen, including that of the SPG missionaries; specific problems and issues in the various settlements, particularly if these involved FrenchEnglish/Catholic-Protestant relations, as it sometimes did. In short, virtually everything connected with those French Canadians in Royal Institution schools was examined and analysed. The evidence found reinforced Audet's conclusions.

Despite having been used extensively in the studies quoted above, the Royal Institution documents still contained substantial information for historians interested in educational, church, social, and regional history. Unfortunately, because of its bulk and its organization, this correspondence could be examined only with a great expenditure of time and effort. 
In 1972 , this writer made part of this documentation more readily available to researchers in a Ph.D. thesis presented to the Department of History of McGill University: "The Royal Institution for the Advancement of Learning: The Correspondence, 1820-1829, A Historical and Analytical Study." This was a voluminous work, 1,423 pages in five volumes.

The purpose of the thesis was threefold: a historiographical review and analysis of writings on the Royal Institution from 1832 to 1964; a detailed account of the totality of Royal Institution activities in Lower Canada - studies of 116 seigneuries and townships; a reorganziation of that correspondence pertinent to public education from 1820 to 1829 . The chronological limits represented the period when the Royal Institution was concerned more specifically with public education.

The problem of consulting the Royal Institution documents in the MUA, particularly the incoming correspondence, was that they were organized only chronologically. There was no index nor inventory, and because the correspondence was so voluminous, literally thousands of letters, there was no other way to find information except to read through the whole mass of the correspondence.

The task of compiling an index would be overwhelming. However, that of providing an inventory and summaries, although considerable, was feasible. It required making a careful summary of each letter and introducing some kind of structure to organize the data.

Because the focus of the thesis was on Royal Institution activities in the seigneuries and townships, the basic organization of the inventory was geographical as well as chronological. The summary of each letter was filed chronologically according to the settlement where the school was located, and because very often letters contained information about more than one school or more than one area, each summary was cross referenced and copies filed under each area mentioned. For example, the Rev. Thomas Johnson, Rector of Hatley, visited a very large number of schools. Often his reports contained information about more than one school, and more than one settle- ment. Thus, the entry for a letter from Johnson to the Rev. J. L. Mills, the Secretary of the Royal Institution, written on January 20, 1825 would contain the following information:

1. reference to the MUA: Accession 447/11, (now R.G.4, c.41, f.9525);

2. correspondents: Johnson to Mills;

3. date: 20 January 1825 ;

4. identification of areas concerned:

Hatley (Village)

Hatley (Church District)

Compton

Barnston

Stanstead

Seigneurie of St. Hyacinthe, Yamaska Mountain Settlement;

5. a summary of the letter, filed under each of these areas.

The correspondence referring to these seigneuries and townships was classified further under each of the administrative districts of Lower Canada: Montreal, Three Rivers, Quebec, and the unorganized District of Gaspe. The seigneuries and townships in each district were organized according to the topographical description of British North America prepared by the surveyor Joseph Bouchette in $1832 .^{36}$ The District of Montreal contained Royal Institution information on thirty seigneuries and thirty townships; the District of Three Rivers, six seigneuries and eleven townships; the District of Quebec, twenty-five seigneuries and two townships; the District of Gaspe, twelve settlements. This represented in all 116 areas in Lower Canada which had had some contact with the Royal Institution.

Although there was often more than one school in some seigneurie or township, the summaries were filed only under these major divisions. For example, in Stanstead there were schools in eight settlements: Church District, Capt. Rose's Dist., Moulton's Dist., Major Boynton's Dist., Bebee Plain, Griffin's Corner, and Jones' District. Copies of letters referring to each of these areas were all filed chronologically under the Township of Stanstead. The history of Royal Institution 
activities was to focus on the history of seigneuries and townships, not on that of individual settlements, the exception being those in the unorganized District of Gaspe.

The entry for each of the 116 areas was organized in a similar pattern. There was first a section of historical data on the seigneurie or township, and this was followed by the summaries of all the letters pertinent to the area in strict chronological order.

\section{Historical Data}

1. name of seigneurie or township;

2. county in which located;

3. boundaries (surrounding seigneuries and/or townships);

4. location of the school(s), giving range and lot numbers from the Bouchette surveys where available;

5. description of the population, e.g. American settlement; Irish Protestant settlement; French Canadian majority; large numbers of Methodists; etc...;

6. brief history of the founding of the school;

7. names of all local officials: commissioners, visitors;

8. names of all visiting clergymen, specifically their contribution to the operation of the school, and their influence on the local population;

9. names and dates of appointment of all teachers for each school;

10. narrative of specific problems and issues in the area, particularly if these involved relations French-English/CatholicProtestant, as well as Anglican-Dissenters.

The summaries of all the relevant correspondence followed this historical description, thus providing a complete documentary history of all Royal Institution activities in the seigneuries and townships in Lower Canada from 1820 to 1829 .
These histories and inventories are found in volumes II, III, IV, and V, of the thesis, volume I being the historiographical study of the Royal Institution.

$$
\begin{aligned}
& \text { Vol. II, p. 223-614: Dist. of Montreal, } 30 \text { seigneuries; } \\
& \text { Vol. III, p. 615-905: Dist. of Montreal, } 30 \text { townships; } \\
& \text { Vol. IV, p. 906-1,115: Dist. of Three } 6 \text { seigneuries } \\
& \text { Rivers, } 11 \text { townships; } \\
& \text { 404: } 2 \text { townships; } \\
& \text { Dist. of Gaspe, } 12 \text { settlements. }
\end{aligned}
$$

Of course there are limitations to this inventory. First, it covers only the period from 1820 to 1829 . Secondly, it includes only data pertinent to public education. Thirdly, it focuses exclusively on Royal Institution activities at the local level. Therefore, it does not include correspondence concerned specifically with the central administration of the Royal Institution, church-state relations, nor the development of McGill College. These topics were all covered completely and fully by Audet in his two volume history which includes all pertinent references to the Royal Institution correspondence. Finally, there is no index. Researchers wanting only specific information, for example, on some clergyman or teacher, or on textbooks and curriculum, must leaf through the individual studies of the seigneuries and townships. Of course, it is still much easier and faster to do this than to have to read, and decipher the handwriting (at times a difficult task) of thousands of actual letters. If a particular summary proves interesting, the reference is available to seek the original document in the MUA. Obviously, much archival work still remains to be done to make the Royal Institution correspondence more readily available to researchers. This partial inventory was a start.

This correspondence still has much to offer scholars. The social historian, for example, will find information relating to the lives of ordinary people: school budgets, cost of construction and repair of schools, teacher's salaries and pensions, family budgets, patterns and styles of living, levels of poverty in pioneer settlements, the state of roads and communications, etc... The church historian can study the involvement of SPG missionaries in pioneer settlements and evaluate their influence 
on the people, as well as their relations with the dissenters, particularly with the Methodists. Local historians can find a mine of information about various aspects of the history of some 61 seigneuries, 43 townships, and the 12 settlements in Gaspe.

For example, this writer has been using the Royal Institution correspondence recently to delve further into the activities of the Anglican clergy in education in Lower Canada. A study of the educational policies of the Church of England presented in $1986^{37}$ has led to another which will highlight principally the work of the SPG missionaries. ${ }^{38}$ The Royal Institution correspondence contains data for many more such studies.

\section{Notes}

For the history of McGill University, see: Cyrus Macmillan, McGill and Its Story, 1821-1921 (Toronto: Oxford University Press, 1921); Stanley Brice Frost, McGill University for the Advancement of Learning, vol. 1, 1801-1895 (Montreal: McGill-Queen's University Press, 1980); and, Stanley Brice Frost, McGill University for the Advancement of Learning, vol. 2, 1895-1971 (Montreal: McGill-Queen's University Press, 1984).

1. Anno quadragesimo primo Georgii III. A.D. 1801. CAP. XVII. An Act for the Establishment of Free Schools and the Advancement of Learning in the Province.

2. The instructions to the governors made this quite clear. See the instructions to Murray (1763) and Carleton (1768) in: Adam Shortt and Arthur G. Doughty, eds., Documents Relating to the Constitutional History of Canada, 1759-1791 (Ottawa: King's Printer, 1918), 181-205; 301-324.

3. Thomas R. Millman, Jacob Mountain, First Lord Bishop of Quebec, A Study in Church and State, 1793-1825 (Toronto: University of Toronto Press, 1947), 171.

4. John Wilfrid Netten, "The Anglican Church: Its Influence on the Development of Education in the Province of Quebec From 1760-1900," (M.Ed. diss., Bishop's University, 1966), 78-79; and Réal G. Boulianne, "The Royal Institution for the Advancement of Learning: The Correspondence, 1820-1829, A Historical and Analytical Study," (Ph.D. diss., McGill University, 1970), 1:12.

5. Boulianne, “The Royal Institution," 1:14.

6. Augustus Wolff of Berthier and Edmund Victor Baron de Koenig of L'Islet were cases in point. See: Ibid., 2:607, and 5:1, 238.

7. Netten, "The Anglican Church," 82-83.

8. Ibid., 83.

9. Ibid., 81 .

10. Ibid.

11. Ibid., 81-82. 
12. The initial Board of Trustees was composed of:

The Lieutenant-Governor of Upper Canada

The Lord Bishop of Quebec

Jonathan Sewell, Chief Justice of Lower Canada

James Monk, Chief Justice, Court of the King's Bench, Montreal

The Chief Justice of Upper Canada

The Speaker of the Legislative Council, Lower Canada

The Speaker of the House of Assembly, Lower Canada

John Richardson, Executive Council, Lower Canada

Ross Cuthbert, Executive Council, Lower Canada

The Rev. John Strachan, Executive Council, Upper Canada

13. Boulianne, "The Royal Institution," 1:16.

14. Louis-Philippe Audet, Le Système scolaire de la Province de Québec, (Québec: les Presses universitaires Laval, 1952), 4:182.

15. Audet devotes all of Chapter 2 to this topic: Ibid., 4:21-105.

16. Ibid., 4:95-96.

17. Ibid., 4:182.

18. Audet, Le Système scolaire de la Province de Québec, vol. 3, L'Institution Royale, Les débuts: 1801-1825, and vol. 4, L'Institution Royale, Le déclin: 1825-1846.

19. F.-X. Garneau, Histoire du Canada, $8^{\mathrm{e}}$ édition (Montréal: Editions de l'Arbre, 1945), 7:51-52.

20. J.-B. Meilleur, Mémorial de l'Éducation du Bas-Canada (1615-1865), 2e édition (Québec: Léger Brousseau, 1876).

21. Ibid., 118.

22. 1 bid.

23. George W. Parmelee, "English Education," in Canada and Its Provinces, eds. Adam Shortt and Arthur G. Doughty (Toronto: Glasgow, Brook and Co., 1914), 16:445-501.
24. Cyrus Macmillan, McGill and Its Story, 1821-1921 (Toronto: Oxford University Press, 1921).

25. Lionel Groulx, L'Enseignement franfais au Canada, Tome 1. Dans le Québec (Montréal: Librairie d'Action canadienne-française, 1931), 75.

26. Ibid., 77-78.

27. Jean Bruchési, Histoire du Canada (Montréal: Beauchemin, 1951). Robert Rumilly, Histoire du Canada (Paris: La Clé d'Or, 1951). Mason Wade, The French Canadians, 1760-1945 (Toronto: Macmillan, 1955).

28. Arthur M. Lower, Colony to Nation, $A$ History of Canada (Toronto: Longmans, Green, 1946), 156-157.

29. Louis-Philippe Audet, "La loi scolaire de 1801," Mémoires de la Société Royale du Canada 42 (Troisième Série, mai 1948), 5.

30. The letters are no longer bundled in packets but unfolded and in acid free folders.

31. Audet, Le Système scolaire, 4:391-392.

32. Louis-Philippe Audet, "Deux Écoles royales, 1814-36: Sainte-Marie de la Nouvelle Beauce et Cap Santé," Mémoires de la Société Royale du Canada 50 (Troisième Série, juin 1956), 24.

33. Audet, Le Système scolaire, 3:136.

34. Réal G. Boulianne, "The French Canadians and the Schools of the Royal Institution for the Advancement of Learning, 1820-1829," Histoire Sociale/Social History 5 (no. 10, November 1972), 160-161.

35. Ibid., 144-164.

36. Joseph Bouchette, The British Dominions in North America; or A Topographical and Statistical Description of the Provinces of Lower and Upper Canada, New Brunswick, Nova Scotia, the Islands of Newfoundland, Prince Edward, and Cape Breton. Including Considerations on Land-granting and Emigration. To which are annexed, Statistical Tables and Tables of Distances, 2 vols., (London: Longman, 1832). 
37. Réal G. Boulianne, "The Church of England and Educational Policy in Early 19th Century Lower Canada," (Paper delivered to the Canadian History of Education Association, Halifax, N.S., 19 October, 1986).

38. The author is now working on the manuscript of a book entitled tentatively, The Cburch of England Clergy and Education in Lower Canada, 1793-1829.

Although the Royal Institution documents are a major source for this study, they have been complemented by Church of England papers in Lambeth Palace, London, and the SPG correspondence in Rhodes House, Oxford. This research was supported by a grant from the Social Sciences and Humanities Research Council of Canada. 